\title{
EFEKTIVITAS MEDIA KOMIK PADA MATERI SIFAT-SIFAT BANGUN RUANG UNTUK SISWA KELAS V SD NEGERI 6I KOTA BENGKULU
}

\author{
${ }^{1}$ Desi Kurniati, ${ }^{2}$ Dewi Rahimah, ${ }^{3}$ Rusdi \\ ${ }_{1,2,3}$ Prodi Pendidikan Matematika JPMIPA FKIP Universitas Bengkulu \\ Email : ${ }^{1}$ desikurniati197@gmail.com, ${ }^{2}$ rahimah_dewi@yahoo.com, ${ }^{3}$ rusdipendmat12@gmail.com
}

\begin{abstract}
Abstrak
Penelitian ini bertujuan untuk mendeskripsikan tingkat keefektifan dari media komik pada materi sifatsifat bangun ruang untuk siswa kelas V SD Negeri 61 Kota Bengkulu. Jenis penelitian yang digunakan ialah penelitian pengembangan (Research and Development). Efektifitas diuji pada 30 orang siswa kelas VB SD Negeri 61 Kota Bengkulu semester genap tahun ajaran 2016/2017. Indikator efektifitas media komik dilihat dari kriteria aktivitas siswa dalam kegiatan pembelajaran, kriteria respon siswa terhadap pembelajaran dan rata-rata hasil belajar. Hasil penelitian menunjukkan bahwa komik yang dikembangkan dikategorikan efektif dengan pencapaian efektivitas: (1) Aktivitas siswa aktif dengan skor rata-rata aktivitas siswa sebesar 3,93 ; (2) Respon siswa terhadap proses pembelajaran yaitu sangat baik dengan skor rata-rata sebesar 4,05 ; (3) Hasil belajar siswa kelas VB SD Negeri 61 Kota Bengkulu efektif dengan ketuntasan belajar klasikal siswa mencapai 76,67\% dan nilai rata-rata sebesar 79,31.
\end{abstract}

Kata Kunci: penelitian pengembangan, efektivitas, media komik.

\begin{abstract}
The study aimed to describe the level of effectiveness of the comic media on the subjects of the three dimentionals characters for Student's Grade V SD Negeri 61 Kota Bengkulu. The research type is research development. Effectiveness was tested on 30 students of grade VB SD Negeri 61 Kota Bengkulu even semester of academic year 2016/2017. The indicators of effectiveness of comic media seen from the criteria of student activity in learning activities, criteria of student response to learning and average learning outcomes. The results showed that the comics developed were categorized effective with the achievement of effectiveness: (1) Active student activity with average score of student activity 3,93; (2) Student response to the learning process is very good with an average score of 4,05; (3) The result of student learning VB SD Negeri 61 Kota Bengkulu effective with the completeness of learning classical students reach 76,67\% and the average value of 79,31.
\end{abstract}

Keywords: development research, effectiveness, comic media.

\section{PENDAHULUAN}

Dalam mengembangkan kreativitas dan kompetensi siswa, maka guru hendaknya dapat menyajikan pembelajaran yang efektif dan efisien sesuai dengan kurikulum dan pola pikir siswa (Heruman, 2010:2). Pembelajaran yang efektif adalah pembelajaran yang membawa siswa mencapai tujuan pembelajaran yang diharapakan. Sedangkan pembelajaran yang efisien adalah aktivitas pembelajaran yang berlangsung menggunakan waktu dan sumber daya yang efisien. Agar pembelajaran dapat menjadi efektif dan efisien, selain dengan memberikan metode pembelajaran yang lebih variatif, guru juga harus mengembangkan bahan ajar sebagai sumber belajar bagi siswa yang lebih inovatif lagi. 
Hingga saat ini proses pembelajaran matematika disekolah masih tergolong kurang efektiv. Hal ini terlihat dari proses pembelajaran matematika di kelas V SD Negeri 61 Kota Bengkulu yakni proses pembelajaran masih berpusat pada guru. Media pembelajaran matematika yang digunakan di kelas ternyata kurang efektif membantu siswa dalam memahami konsep sehingga hasil belajar siswa yang diharapkan kurang yaitu hanya $66 \%$ dari kreteria ketuntasan minimal yang ditentukan yaitu $70 \%$.

Untuk mengatasi masalah tersebut, diperlukan suatu media inovatif yang dapat meningkatkan keefektifan proses pembelajaran matematika dikelas salah satunya yakni dengan menggunakan media komik.

Komik merupakan bacaan yang paling diminati oleh anak-anak karena mudah dicerna dan mengandung humor sehingga komik dapat dijadikan media pembelajaran yang dapat mendukung tercapainya tujuan pembelajaran. Pernyataan tersebut ternyata didukung oleh beberapa pendapat ahli. Rohani (2014:78) menyebutkan bahwa komik merupakan suatu bentuk cerita bergambar yang terdiri atas berbagai situasi cerita bersambung, dan bersifat humor. Mustikan (2013:3) mengungkapkan bahwa penggunaan bahan ajar komik dapat dijadikan alternatif sebagai sumber belajar yang dapat menunjang keberhasilan tujuan pembelajaran.

Komik dapat menjadi sebuah bacaan yang berarti bagi siswa apabila komik yang dibuat mengandung unsur edukatif. Sejalan dengan hal tersebut, Novianti, dkk (2010:77) komik pembelajaran dalam teknologi pendidikan bersifat edukatif dan menciptakan unsur penyampaian pesan yang jelas serta komunikatif. Dengan begitu, penggunaan media komik yang bersifat edukatif, siswa dapat memperoleh pengetahuan yang baru dengan membaca komik tersebut.

Berdasarkan latar belakang yang telah dijabarkan di atas, maka rumusan masalah dalam penelitian ini adalah:"Bagaimana tingkat keefektifan dari media komik pada materi sifatsifat bangun ruang untuk siswa kelas V SD Negeri 61 Kota Bengkulu?".

Berdasarkan rumusan masalah yang ada, maka tujuan yang dicapai dalam penelitian ini adalah "Mendeskripsikan tingkat keefektifan dari media komik pada materi sifat-sifat bangun ruang untuk siswa kelas V SD Negeri 61 Kota Bengkulu".

\section{METODE}

\section{Jenis Penelitian}

Penelitian ini menggunakan jenis penelitian pengembangan. Menurut Borg and Gall (1983) dalam Setyosari (2013:276) penelitian pengembangan adalah suatu jenis penelitian yang digunakan untuk mengembangkan dan menghasilkan sebuah produk pendidikan. Produk yang dikembangkan ialah media komik pada materi sifat-sifat bangun ruang untuk siswa kelas V SD Negeri 61 Kota Bengkulu.

\section{Subjek Penelitian}

Subjek pada penelitian pengembangan ini adalah siswa kelas V SD Negeri 61 Kota Bengkulu tahun ajaran 2016/2017. Pada tahap uji efektifitas komik diuji cobahkan di kelas VB dengan jumlah siswa sebanyak 30 orang.

\section{Teknik Pengumpulan Data}

Data keefektifan media komik diperoleh dari lembar pengamatan aktivitas siswa pada proses pembelajaran, lembar angket respon siswa terhadap proses pembelajaran, hasil pengerjaan soal latihan pada komik dan lembar tes hasil belajar siswa.

\section{Teknik Analisis Data}

Skor rata-rata aktivitas siswa dihitung dengan rumus :

$\bar{A}_{\text {siswa }}=\frac{\sum_{i=1}^{n} \bar{A}_{i}}{n} \quad$ (Rumus Rata-Rata Hitung Diadaptasi dari Sudjana, 2005)

Keterangan :

$\bar{A}_{\text {siswa }}=$ skor rata-rata aktivitas siswa

$\bar{A}_{i}=$ skor rata-rata aktivitas pertemuan ke-i

$n=$ banyak pertemuan 
Skor rata-rata respon siswa dihitung dengan rumus :

$\bar{R}=\frac{\sum_{i=1}^{n} \bar{R}_{i}}{n} \quad$ (Rumus Rata-Rata Hitung

Diadaptasi dari Sudjana, 2005)

Keterangan :

$\bar{R}=$ skor rata-rata respon siswa

$\bar{R}_{i}=$ skor rata-rata respon siswa ke-i

$n=$ banyak siswa

Skor hasil belajar siswa diperoleh dari $75 \%$ nilai Tes Hasil Belajar dan $25 \%$ nilai pengerjaan latihan soal pada komik. Hasil belajar siswa dikatakan berhasil apabila mencapai KKM yakni 70. Pemberian skor hasil belajar dapat dilihat pada tabel 1.

Tabel 1 Kriteria Penilaian Pencapain Akademik

\begin{tabular}{|c|c|c|}
\hline $\begin{array}{c}\text { Interval Presentase } \\
\text { Ketuntasan }\end{array}$ & Skor & Keterangan skor \\
\hline $\begin{array}{c}\text { Presentase ketuntasan } \\
>80\end{array}$ & $\mathbf{5}$ & Sangat baik \\
\hline $60<\%$ ketuntasan $\leq 80$ & 4 & Baik \\
\hline $40<\%$ ketuntasan $\leq 60$ & 3 & Cukup \\
\hline $20<\%$ ketuntasan $\leq 40$ & 2 & Kurang \\
\hline$\%$ ketuntasan $\leq 20$ & 1 & Sangat kurang \\
\hline
\end{tabular}

Sumber : Widoyoko (2009 : 242)

Sehingga skor rata-rata efektivitas dihitung menggunakan rumus:

$$
\bar{E}=\frac{(\bar{A} \times 30 \%)+(\bar{R} \times 30 \%)+(\bar{H} \times 40 \%)}{100 \%}
$$

Keterangan :

$\bar{E}=$ skor rata-rata efektivitas

$\bar{A}=$ skor rata-rata aktivitas

$\bar{R}=$ skor rata- rata respon siswa

$\bar{H}=$ skor rata-rata hasil belajar siswa

Kriteria efektivitas produk yaitu:

Tabel 2 Kriteria Efektivitas Produk

\begin{tabular}{|c|c|c|}
\hline Interval skor & Kriteria & Keterangan \\
\hline $\bar{E}<1,8$ & $\begin{array}{c}\text { Tidak } \\
\text { Efektif }\end{array}$ & $\begin{array}{c}\text { Tidak dapat digunakan } \\
\text { dan perlu perubahan total }\end{array}$ \\
\hline $2,8 \leq \bar{E}<2,6$ & $\begin{array}{c}\text { Kurang } \\
\text { Efektif }\end{array}$ & $\begin{array}{c}\text { Tidak dapat digunakan } \\
\text { dan perlu sedikit } \\
\text { perubahan }\end{array}$ \\
\hline $3,4 \leq \bar{E}<3,4$ & $\begin{array}{c}\text { Cukup } \\
\text { Efektif }\end{array}$ & $\begin{array}{c}\text { Dapat digunakan dengan } \\
\text { banyak perbaikan }\end{array}$ \\
\hline $\bar{E} \geq 4,2$ & Efektif & $\begin{array}{c}\text { Dapat digunakan dengan } \\
\text { sedikit perbaikan }\end{array}$ \\
\hline
\end{tabular}

Efektif $\quad$ perbaikan

Sumber : Diadaptasi dari Maizora (2011)

\section{HASIL DAN PEMBAHASAN}

Uji efektifitas dilakukan untuk mengetahui efektifitas komik di dalam pembelajaran. Uji efektifitas dilakukan di kelas VB SD Negeri 61 Kota Bengkulu dengan jumlah siswa sebanyak 30 orang. Keefektifan komik diukur dari aktivitas siswa saat proses pembelajaran, respon siswa terhadap pembelajaran dan hasil belajar siswa. Ketiga alat ukur tersebut menggunakan lembar pengamatan aktivitas siswa diisi oleh pengamat, lembar angket respon siswa yang diisi oleh siswa, serta hasil belajar siswa yang diperoleh dari hasil penilaian latihan pada komik dan tes hasil belajar.

Data hasil aktivitas siswa dilihat dari lembar pengamatan aktivitas siswa yang diisi oleh pengamat pada setiap pertemuan. Skor rata-rata aktivitas siswa dalam tiga pertemuan disajikan pada tabel 3 berikut.

Tabel 3 Skor Rata-Rata Aktivitas

\begin{tabular}{|c|c|c|}
\hline $\begin{array}{c}\text { Pertemuan } \\
\text { ke }\end{array}$ & $\begin{array}{c}\text { Skor rata-rata } \\
\text { aktivitas }\end{array}$ & Kriteria \\
\hline 1 & 3,60 & Aktif \\
\hline 2 & 4,10 & Aktif \\
\hline 3 & 4,10 & Aktif \\
\hline Rata-rata & $\mathbf{3 , 9 3}$ & Aktif \\
\hline
\end{tabular}

Berdasarkan tabel 3 menunjukkan bahwa ratarata total aktivitas siswa selama proses pembelajaran menggunakan komik diperoleh skor 3,93 yang berkategori "aktif".

Skor rata-rata aktivitas siswa yang paling tinggi didapat oleh indikator aktivitas siswa ke 4 yang berarti siswa telah mampu mengerjakan soal latihan dalam komik dengan baik sebagai penerapan konsep yang telah diperoleh setelah membaca komik. Hal ini menunjukkan bahwa materi-materi yang disajikan di dalam komik mampu memfasilitasi siswa untuk dapat menjawab soal latihan dengan baik.

Sedangkan skor terendah didapat oleh indikator aktivitas siswa ke 2 yang berarti aktivitas siswa dalam membuat pertanyaan yang 
berhubungan dengan materi yang dipelajari di komik masih belum cukup baik. Secara keseluruhan, aktivitas siswa dan guru saat proses pembelajaran menggunakan komik ini sudah baik. Hal ini ditunjukkan dengan hasil pengamatan oleh pengamat yang mengisi lembar pengamatan aktivitas siswa.

Data respon siswa diperoleh dari lembar respon siswa yang diisi oleh siswa pada setiap pertemuan. Respon siswa ini digunakan untuk melihat bagaimana pendapat siswa terhadap proses pembelajaran dengan menggunakan komik yang dikembangkan dalam penelitian ini. Secara keseluruhan, respon siswa terhadap komik yang dikembangkan dalam penelitian ini sudah baik. Hal ini ditunjukan dengan skor rata-rata respon siswa yang memperoleh nilai 4,05 dengan kategori "baik"

Hasil belajar siswa diperoleh dari $25 \%$ nilai hasil pengerjaan soal latihan pada komik dan $75 \%$ nilai tes hasil belajar. Tes hasil belajar diberikan pada pertemuan keempat setelah tiga kali pertemuan belajar dengan menggunakan komik. Tes hasil belajar ini diikuti oleh 29 siswa dari 30 siswa yang ada. Hal ini dikarenakan 1 siswa tidak hadir saat tes hasil belajar dilaksanakan. Lembar tes hasil belajar terdiri dari 10 soal ganda yang disusun berdasarkan indikator yang ingin dicapai pada materi sifatsifat bangun ruang.

Komik yang diujicobakan oleh siswa pada saat proses pembelajaran ternyata mempunyai pengaruh terhadap pemahaman siswa pada materi sifat-sifat bangun ruang yang berdampak pada hasil belajarnya. Hal ini dapat dilihat dari jawaban-jawaban siswa pada latihan di setiap komik dan tes hasil belajar.

Nilai rata-rata latihan tertinggi untuk seluruh komik adalah 98 dan nilai terendah adalah 73 . Artinya selisih nilai tertinggi dan terendah yang diperoleh cukup jauh. Hasil pekerjaan siswa yang paling rendah kemudian dianalisis dan diketahui bahwa rata-rata kesalahan siswa terdapat pada kesalahan penggambaran bangun ruang. Hal ini menunjukkan bahwa siswa belum memiliki keterampilan menggambar yang baik. Gambar 1 menunjukkan jawaban salah satu siswa yang mendapat nilai terendah dengan kesalahan terletak pada penggambaran bangun ruang balok dan bangun ruang tabung.

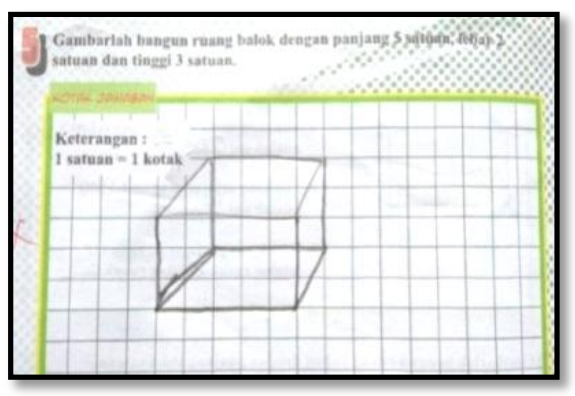

Gambar 1 Kesalahan Penggambaran Pada Bangun Ruang Balok

Setelah dianalisis dari beberapa jawaban siswa yang salah diketahui penyebab siswa masih salah dalam menggambarkan bangun ruang dikarenakan pada bagian komik 1 masih terdapat penyajian gambar bangun ruang balok yang salah. Gambar bangun ruang balok yang masih salah tersebut dapat ditunjukkan pada gambar 2 berikut.

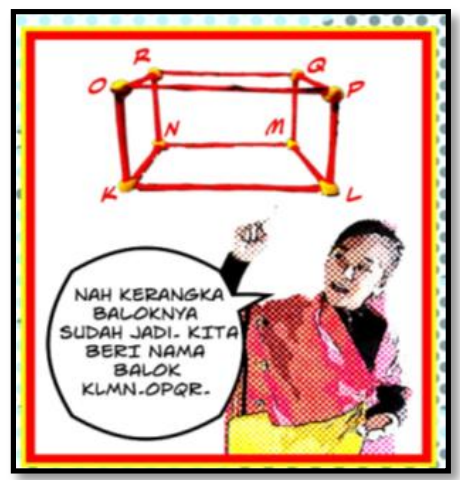

Gambar 2 Gambar Bangun Ruang Balok Yang Masih Salah

Penggambaran bangun ruang balok yang masih salah terjadi karena kesalahan pada saat pengambilan gambar sehingga yang terlihat bukan seperti bangun ruang balok tetapi terlihat seperti prisma trapesium. Dengan demikian peneliti melakukan revisi kembali pada komik 1 tepatnya pada gambar bangun ruang balok tersebut. Berikut gambar balok setelah direvisi. 


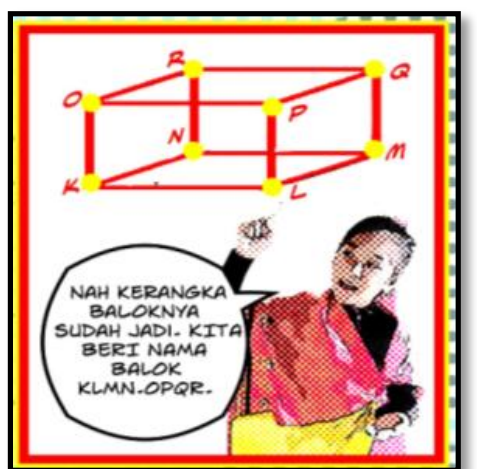

\section{Gambar 3 Gambar Bangun Ruang Balok Setelah Direvisi}

Untuk rekap penilaian presentase ketuntasan belajar siswa secara ringkas dapat dilihat pada tabel 4 berikut.

Tabel 4 Presentase Ketuntasan Hasil Belajar Siswa

\begin{tabular}{|c|c|c|}
\hline Uraian & Jumlah & Presentase \\
\hline $\begin{array}{c}\text { Siswa Yang } \\
\text { Tuntas }\end{array}$ & 23 & $76,67 \%$ \\
\hline $\begin{array}{c}\text { Siswa Yang } \\
\text { Tidak Tuntas }\end{array}$ & 7 & $23,33 \%$ \\
\hline
\end{tabular}

Nilai rata-rata tes hasil belajar yaitu 79,31. Artinya rata-rata nilai tes hasil belajar secara keseluruhan sudah bagus. Dengan demikian berdasarkan hasil penelitian, ketuntasan belajar siswa selama uji efektifitas yaitu diperoleh 23 siswa yang tuntas dan 7 siswa yang belum tuntas atau presentase ketuntasan mencapai $76,67 \%$. Menurut Widoyoko (2009:242) persentase ketuntasan belajar ini terletak pada kriteria "baik" dengan memperoleh skor 4. Hal ini berarti siswa sudah mampu menerapkan konsep yang didapat pada saat menggunakan komik dengan mengerjakan latihan di komik dan menyelesaikan soal tes hasil belajar yang diberikan.

Skor rata-rata efektivitas diperoleh dengan rumus sebagai berikut.

$$
\begin{aligned}
\bar{E} & =\frac{(\bar{A} \times 30 \%)+(\bar{R} \times 30 \%)+(\bar{H} \times 40 \%)}{100 \%} \\
& =\frac{(3,93 \times 30 \%)+(4,05 \times 30 \%)+(4 \times 40 \%)}{100 \%} \\
= & 3,99
\end{aligned}
$$

Dengan demikian, berdasarkan hasil lembar pengamatan aktivitas siswa, lembar respon siswa, dan hasil belajar siswa diperoleh skor rata-rata keefektifan komik yaitu 3,99 yang berkategori "efektif".

\section{PENUTUP \\ Simpulan}

Berdasarkan hasil penelitian pada efektivitas media komik pada materi sifat-sifat bangun ruang untuk siswa Kelas V SD Negeri 61 Kota Bengkulu diperoleh simpulan bahwa media komik pada pokok bahasan sifat-sifat bangun ruang untuk siswa kelas V SD Negeri 61 Kota Bengkulu termasuk dalam kategori efektif dengan skor rata-rata 3,99 karena:

a. Aktivitas siswa dalam kegiatan belajar yaitu berkategori aktif dengan skor rata-rata sebesar 3,93.

b. Respon siswa terhadap proses pembelajaran yaitu sangat baik dengan skor rata-rata sebesar 4,05.

c. Hasil belajar siswa kelas VB SD Negeri 61 Kota Bengkulu efektif karena ketuntasan belajar klasikal siswa telah mencapai 76,67\% dengan KKM yaitu 70 dan nilai rata-rata sebesar 79,31.

\section{Saran}

Berdasarkan penelitian yang telah dilakukan peneliti pada penelitian efektivitas media komik pada materi sifat-sifat bangun ruang untuk siswa Kelas V SD Negeri 61 Kota Bengkulu disarankan beberapa hal berikut:

1. Komposisi cerita yang disajikan di dalam komik sebaiknya disesuaikan dengan alokasi waktu pembelajaran.

2. Berdasarkan respon siswa diketahui bahwa siswa sangat menyukai belajar matematika dengan menggunakan media komik, sehingga diharapkan pada penelitian selanjutnya dapat dikembangkan komik matematika lain dengan pokok bahasan yang berbeda.

\section{DAFTAR PUSTAKA}

Heruman. 2010. Model Pembelajaran Matematika di Sekolah Dasar. Bandung: Remaja Rosdakarya. 
Maizora, Syafdi. 2011. "Pengembangan Web Pembelajaran Kalkulus Diferensial pada Program Studi Pendidikan Matematika FKIP Universitas Bengkulu”. Tesis tidak diterbitkan. Tesis Konsentrasi Pendidikan Matematika Program Pascasarjana UNP.

Mustikan. 2013. "Penggunaan Bahan Ajar Komik Untuk Meningkatkan Minat Belajar IPA". Jurnal Seminar Nasional 2nd Lontar Physics Forum 2013. Hal 1-7.

Novianti, Riska Dwi, dkk. 2010. "Pengembangan Media Komik Pembelajaran Matematika Untuk Meningkatkan Pemahaman Bentuk Soal Cerita Bab Pecahan Pada Siswa Kelas V SDN Ngembung". Jurnal Teknologi Pendidikan Vol.10 N0.1 April 2010. Hal 74-85.

Rohani. Ahmad. 2014. Media Instruksional Edukatif. Jakarta: Rineka Cipta.

Setyosari, Punaji. 2013. Metode Penelitian Pendidikan. Jakarta: Kencana Prenadamedia Group.

Sudjana. 2005. Metode Statistika. Bandung: Tarsito.

Widoyoko, Eko Putro. 2009. Evaluasi Program Pembelajaran. Yogyakarta :Pustaka Pelajar. 